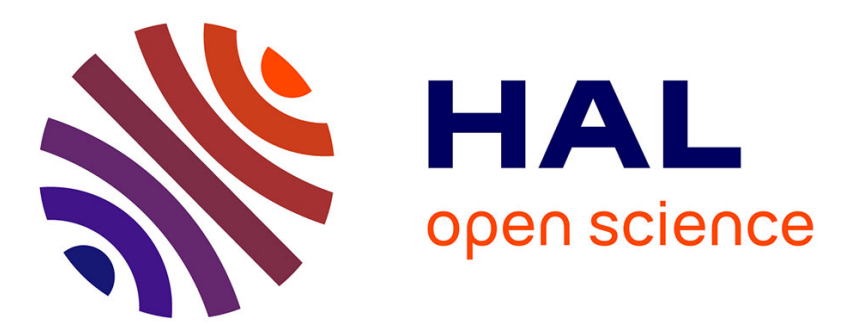

\title{
Acid-base controlled multiple conformation and aromaticity switches in tren-capped hexaphyrins
}

Stéphane Le Gac, Elsa Caytan, Vincent Dorcet, Bernard Boitrel

\section{To cite this version:}

Stéphane Le Gac, Elsa Caytan, Vincent Dorcet, Bernard Boitrel. Acid-base controlled multiple conformation and aromaticity switches in tren-capped hexaphyrins. Organic \& Biomolecular Chemistry, 2019, 17 (15), pp.3718-3722. 10.1039/c9ob00489k . hal-02087814

HAL Id: hal-02087814

https://hal-univ-rennes1.archives-ouvertes.fr/hal-02087814

Submitted on 14 Jun 2019

HAL is a multi-disciplinary open access archive for the deposit and dissemination of scientific research documents, whether they are published or not. The documents may come from teaching and research institutions in France or abroad, or from public or private research centers.
L'archive ouverte pluridisciplinaire HAL, est destinée au dépôt et à la diffusion de documents scientifiques de niveau recherche, publiés ou non, émanant des établissements d'enseignement et de recherche français ou étrangers, des laboratoires publics ou privés. 


\title{
Acid-Base Controlled Multiple Conformation and Aromaticity Switches in Tren-Capped Hexaphyrins
}

\author{
Stéphane Le Gac, ${ }^{\text {a }}$ Elsa Caytan, ${ }^{\text {a }}$ Vincent Dorcet ${ }^{\mathrm{a}}$ and Bernard Boitrel ${ }^{\mathrm{a}}$
}

\begin{abstract}
Upon protonation, a tren-capped hexaphyrin undergoes successive rectangular-to-Möbius and Möbius-to-triangular conformational isomerizations, with concomitant antiaromaticity-to-aromaticity reversal. This affords different cage environments leading ultimately to a "crypto-bowl-shape" hexaphyrin hosting a trifluoroacetate counterion.
\end{abstract}

Coupled conformational and aromaticity changes in expanded porphyrins are an attractive feature in the field of nanoscience. ${ }^{1}$ Indeed, aromatic-antiaromatic switching ${ }^{2}$ could be exploited to form new molecular junctions, ${ }^{3}$ optoelectronic materials ${ }^{4}$ or innovative sensors. ${ }^{5}$

Regular hexaphyrins have been shown to adopt different conformations (Figure 1 ) depending on various factors such as coordination, ${ }^{6}$ protonation, ${ }^{7}$ or solvent polarity, ${ }^{8}$ in strong interplay with their oxidation state $([26 / 28] \pi$-conjugated system). Interestingly, for a given oxidation state, opposite aromatic/antiaromatic characters are obtained upon introducing a single twist in the $\pi$-conjugated system (Möbius conformation). ${ }^{8 a, b}$ Achieving Möbius aromaticity is remarkable in itself, ${ }^{9}$ but remains underexplored in functional systems (devices, receptors...). ${ }^{10}$

Despite the abundant literature on expanded porphyrins, ${ }^{1}$ their coupling to various functional units has been scarcely described. Recently, we have evidenced that capping the hexaphyrin frame with a cyclodextrin unit allows multiple conformational changes (rectangular/triangular or rectangular/dumbbell) depending on the protonation state and/or temperature changes, opening the way to shape-shifting molecular receptors. ${ }^{11}$ Furthermore, with a tren-capped [28]hexaphyrin (2, Scheme 1), selective $\mathrm{Zn}(\mathrm{II})$ metalation at the level of a dipyrrin site, coupled to a cooperative two-guest binding process, induced rectangular-toMöbius isomerization with effective $P / M$ twist chiral induction,

a. Univ Rennes, CNRS, ISCR (Institut des Sciences Chimiques de Rennes) - UMR 6226, F-35000 Rennes, France

b.E-mail: stephane.legac@univ-rennes1.fr.

+ Electronic Supplementary Information (ESI) available: experimental part and selected NMR spectra. See DOI: 10.1039/x0xx00000x concomitantly with an antiaromatic-to-aromatic reversal. ${ }^{5}$ This finding represents the first example of a Möbius-type metalloreceptor, with chiroptical properties of interest for sensing systems.

The conformational flexibility of these capped hexaphyrins is remarkable although counterintuitive, as one could expect restricted conformational freedom due to the triple bridging of the meso positions. The relationship between the size and nature of the bridges and the accessible conformations of the hexaphyrin frame remains to be scrutinized. Hence, pursuing our efforts towards adaptative hexaphyrin based hosts, we describe herein a protonation study with two tren-capped hexaphyrins of different sizes (Scheme 1), resulting in controlled conformation and aromaticity switches and setting the basis for functional systems featuring tuneable cage environments.
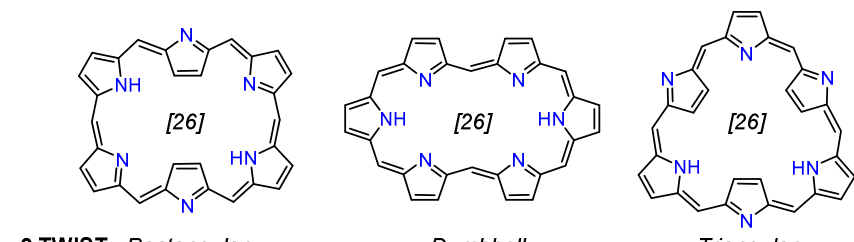

0 TWIST Rectangular

Dumbbell

Triangular
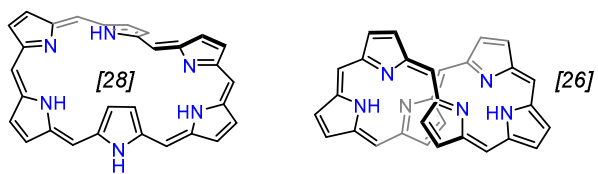

1 TWIST Möbius

2 TWISTS Figure eight

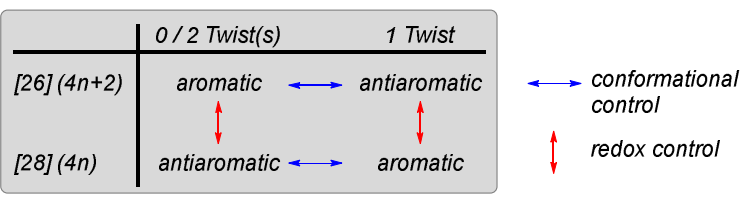

Figure 1. Main conformations of regular hexaphyrins (independently of their [26/28] oxidation state) and interplay between conformation, oxidation state and (anti)aromaticity. 


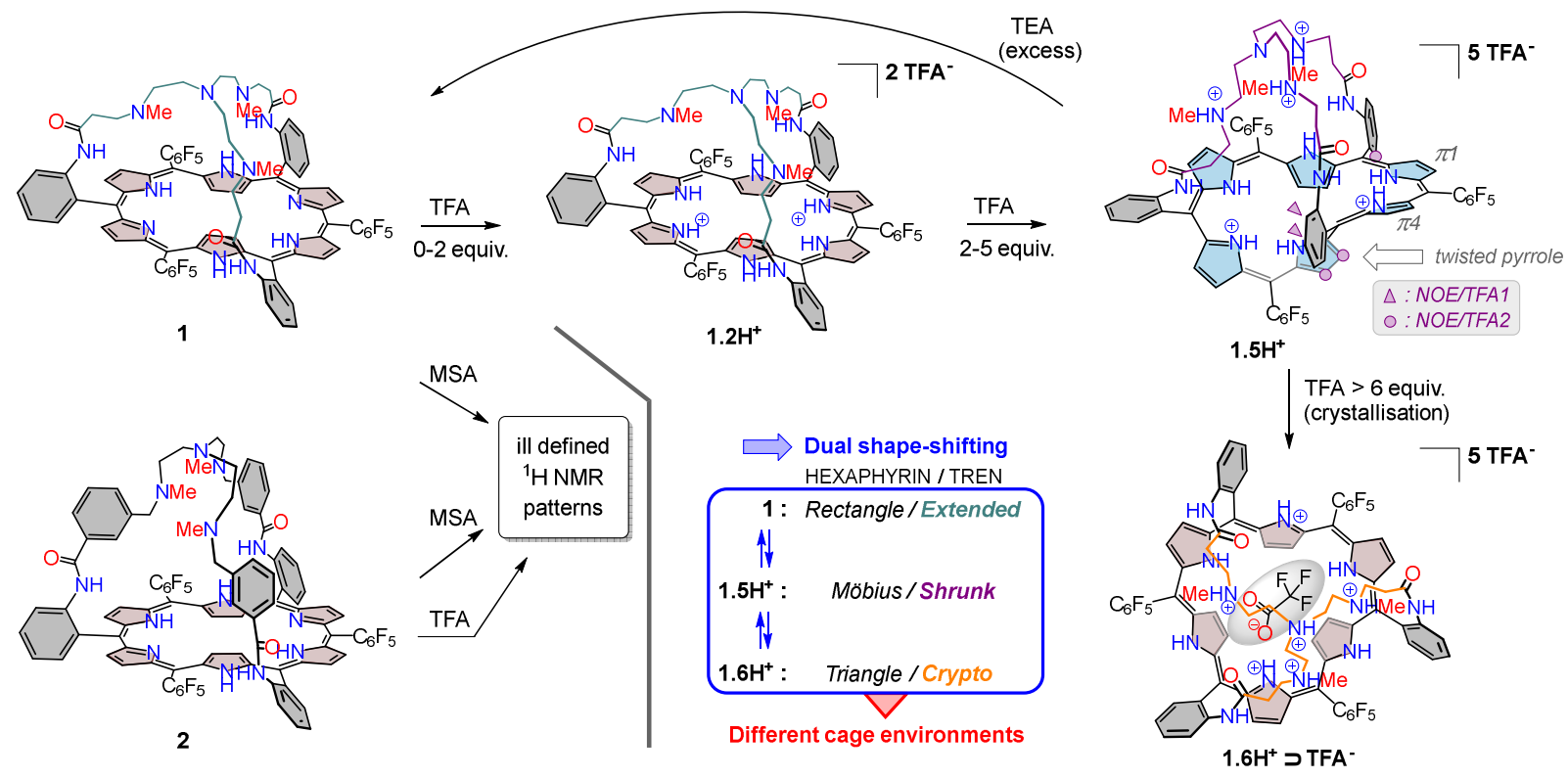

Scheme 1. Protonation study of tren-capped hexaphyrins 1 and $\mathbf{2}$ with TFA and $\mathrm{MSA}$, and induced conformational changes ( $\mathrm{NMR}^{\mathrm{study}}$ at low temperature in $\mathrm{CD}_{2} \mathrm{Cl}_{2}$ or $\mathrm{CDCl}_{3}$ ).

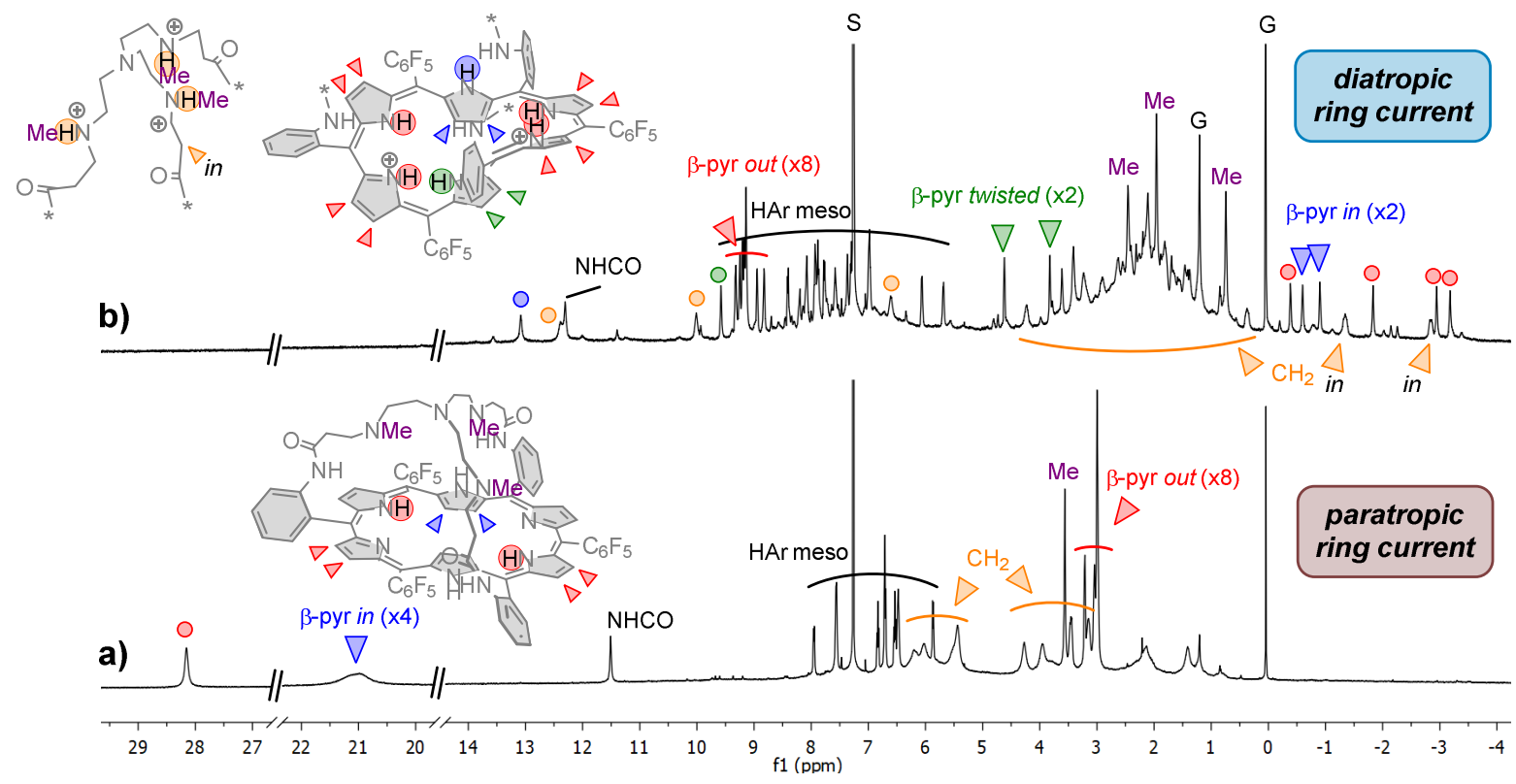

Figure 2. ${ }^{1} \mathrm{H}$ NMR spectra of $1(\mathrm{a})$ and $1.5 \mathrm{H}^{+}(\mathrm{b}$, scale $* 2)\left(\mathrm{CDCl}_{3}, 500 \mathrm{MHz}, 233 \mathrm{~K}\right) . \mathrm{S}=$ solvent, $\mathrm{G}=$ grease.

For both 1 and 2, the hexaphyrins were isolated in their [28] $\pi$ rectangular planar antiaromatic conformation, ${ }^{5}$ with their meso positions linked alternatively to $\mathrm{C}_{6} \mathrm{~F}_{5}$ moieties and the tren unit. $\mathbf{1}$ and $\mathbf{2}$ differ by their attachment of the tris-methylated tren caps to the hexaphyrin, leading to different "crypto" environments. These two compounds afford six protonation sites, two on the hexaphyrin and four on the tren cap.

${ }^{1} \mathrm{H}$ NMR titration experiments of $\mathbf{1}$ and $\mathbf{2}$ with TFA (trifluoroacetic acid) or MSA (methane sulfonic acid) were performed in either $\mathrm{CD}_{2} \mathrm{Cl}_{2}$ or $\mathrm{CDCl}_{3}$, at low temperatures (down 
to $183 \mathrm{~K}, \mathrm{SI}$ ). With 2 bearing a more distant tren cap, nowelldefined patterns were found whatever the conditions, highly broaden signals being observed above 1 eq. of acid (up to 20 eq.), at different temperatures. From a previous study, ${ }^{5} \mathbf{2}$ is flexible enough to undergo rectangular-to-Möbius isomerization upon metalation in specific conditions. The fact that no well-defined species were formed herein suggests a lack of effective conformational stabilization of protonated states. With compound $\mathbf{1}$, the situation was pretty much the same with MSA, whereas titration with TFA at $233 \mathrm{~K}$ in $\mathrm{CDCl}_{3}$ afforded sharp signatures suitable for 2D NMR analysis (SI). Thus, approximately five different patterns were successively observed with increasing amounts of acid. The two first ones (02 eq. of TFA) were consistent with mono- and di-protonated rectangular antiaromatic compounds, namely $1 . \mathrm{H}^{+}$and $\mathbf{1 . 2 \mathrm { H } ^ { + }}$ (Scheme 1), with signals similar to the free base in the deshielded region, above $17 \mathrm{ppm}$, compatible with $\mathrm{NHin} / \beta$ pyrin protons experiencing the paratropic ring current (protonation sites not determined). At ca. 3 eq. of TFA, a third minor unidentified species with drastically different signature was observed (no more deshielded signals, new signals below 0 ppm), that could correspond to 3 or 4 protonated states. Conversely, at ca. 4-5 eq. of TFA, a very well-defined signature was obtained (Figure 2b) corresponding to a major dissymmetric species, assigned to a penta-protonated Möbius compound $\left(\mathbf{1 . 5} \mathrm{H}^{+}\right.$, Scheme 1$)$ through $2 \mathrm{D}$ NMR analysis. Indeed, the hexaphyrin $\beta$-pyrrolic protons distribution fits the characteristic resonances induced by the diatropic ring current of the singly twisted $28 \pi$-conjugated system ${ }^{5}: 2 \mathrm{H}$ at -0.90 and $0.60 \mathrm{ppm}$ (inverted pyrrole), $2 \mathrm{H}$ at 3.82 and $4.62 \mathrm{ppm}$ (twisted pyrrole), and $8 \mathrm{H}$ in the 9.1-9.3 ppm region (four out pyrroles) (respectively blue, green and red triangles, Figure $2 \mathrm{~b}$ ). The in/out distribution is opposite to that of the starting antiaromatic compound 1 (Figure 2a), leading to impressive $\Delta \delta$ of $\sim 22 \mathrm{ppm}$ for the $\beta$-pyrrolic in protons and of $\sim 30 \mathrm{ppm}$ for the NHin protons. In general, the twisting process projects a mesoaromatic group adjacent to the twisted pyrrole towards the inner part of the ring. 2D NOE NMR correlations evidenced that this position corresponds to a meso-aromatic bearing the tren cap, that is de facto constrained in a shrunk conformation as drawn in Scheme 1. The ${ }^{1} \mathrm{H}$ NMR pattern displays two $\mathrm{CH}_{2}$ signals at $-2.84(1 \mathrm{H})$ and $-2.35(1 \mathrm{H}) \mathrm{ppm}$, in agreement with an inward orientation of the tren arm attached to the twisted meso position. Furthermore, three $\mathrm{NH}^{+}$protons of the tren unit were identified at 6.61, 10.00 and $12.40 \mathrm{ppm}$, in addition to the six $\mathrm{NH}$ of the hexaphyrin, attesting the five protonated state of the structure (the fact that further evolution occurs with excess of TFA is consistent with a free remaining protonation site, vide infra).

The ${ }^{19} \mathrm{~F}$ NMR spectrum of $\mathbf{1 . 5 \mathbf { H } ^ { + }}$ exhibits, in addition to the dissymmetric pattern of the meso- $\mathrm{C}_{6} \mathrm{~F}_{5}$ moieties, two sharp singlets $(2 \times 3 F, \delta=-75.66$ ppm ["TFA1"], $\delta=-81.79 \mathrm{ppm}$ ["TFA2"]) as well as a large signal ( $\delta=-75.0$ to $-76.3 \mathrm{ppm})$ in the TFA region. ${ }^{19} \mathrm{~F}$ 2D DOSY NMR reveals an identical diffusion coefficient for TFA1, TFA2 and the meso- $\mathrm{C}_{6} \mathrm{~F}_{5}$ moieties, evidencing that these counterions are strongly associated with $\mathbf{1 . 5 H ^ { + }}(\mathrm{SI})$. Likely, TFA1 and TFA2 are interacting with the diprotonated hexaphyrin unit, in slow exchange on the NMR time scale, whereas those associated to the triprotonated tren cap are averaged, in a fast exchange regime. The highfield shift of ca. $6 \mathrm{ppm}$ of TFA2 vs. TFA1 indicates two different environments that were probed thanks to $1 \mathrm{D}{ }^{1} \mathrm{H}$ detected ${ }^{1} \mathrm{H}$ ${ }^{19} \mathrm{~F}$ nOe-difference NMR experiments (SI), resulting in the following interpretation: (i) TFA1 is associated to the twisted pyrrole, and adopts a lateral position relative to the tren cap (intense NOE with the meso-Ar moieties adjacent to the twisted pyrrole, Scheme 1); (ii) TFA2 is associated to $\pi 1$ or $\pi 4$ and oriented towards the hexaphyrin centre, but opposite to the tren cap (intense NOE with the $\beta$-protons of the twisted pyrrole, Scheme 1). These observations confirm a shrunk conformation of the triprotonated tren cap, which does not afford a crypto environment for hosting a TFA- counterion. Remarkably, addition of excess of triethylamine (TEA) to $\mathbf{1 . 5 \mathbf { H } ^ { + }}$ led back to $\mathbf{1}$ (SI), evidencing an acid-base controlled (anti)aromatic switch

a)

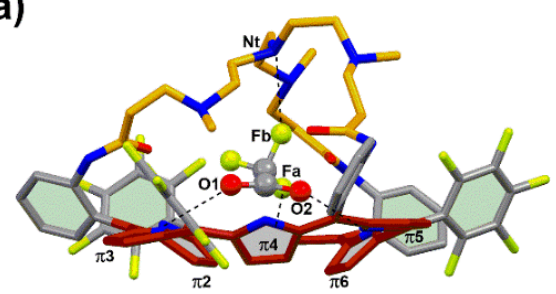

b)

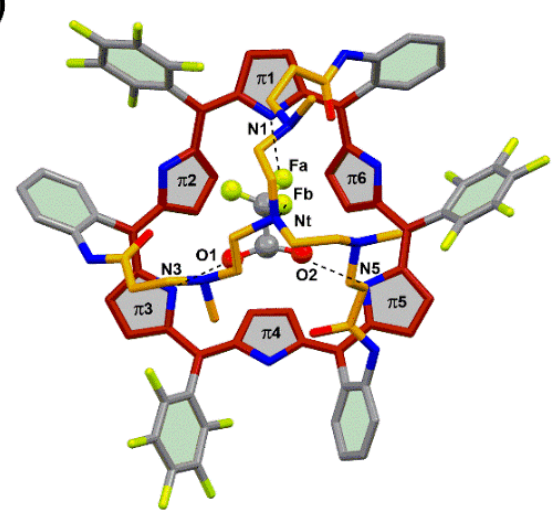

c)

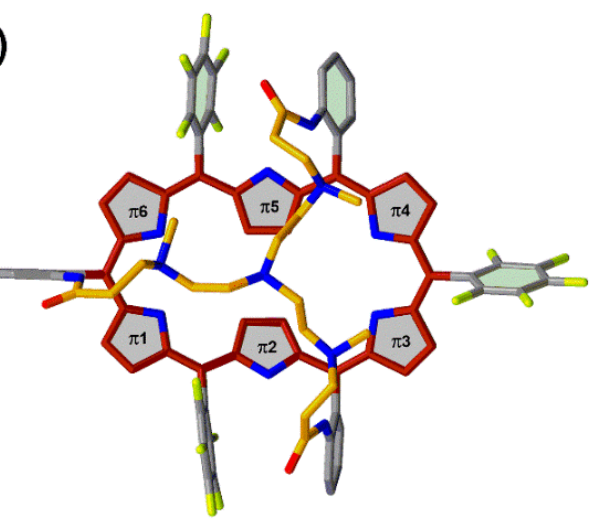

Figure 3. Crystallographic structure of compounds $1.6 \mathrm{H}^{+}$गTFA', (a) side and (b) top views, and $\mathbf{1}(\mathrm{c})$, top view. ${ }^{5} \mathrm{H}$ atoms, solvents of crystallization, and exo-TFA molecules removed for clarity. Hexaphyrin highlighted in dark brown and tren cap in orange, endo-TFA depicted in ball-and-stick. Dashed lines indicate $\mathrm{H}$ bonds. 
(Scheme 1).

With a higher amount of TFA, i.e. $>6$ eq., another species appeared and its NMR pattern broadened with excess of acid, ruling out 2D NMR analysis. This compound, expected to be a 6protonated Möbius state, and exhibiting low solubility in $\mathrm{CDCl}_{3}$, spontaneously crystallised from the NMR tube solution. XRD analysis of these single crystals revealed a triangular hexaphyrin

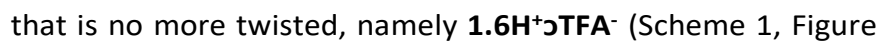
$3 a, b$; Figure $3 c$ shows the previously reported molecular structure of $\left.\mathbf{1}^{5}\right) .{ }^{12}$ Three out pyrroles define the edges of the triangle $(\pi 1, \pi 3, \pi 5)$ whereas the three others are inverted $(\pi 2$, $\pi 4, \pi 6)$ defining the sides. While the out pyrroles are roughly coplanar, the inverted ones are tilted outwards by $c a .40^{\circ}$ defining concave and convex faces, the concave one being capped by the tren unit. The tren is not symmetric, and adopts a somehow distorted crypto conformation. The macrocyclic structure is surrounded by at least seven exo-TFA that contribute to a complex $\mathrm{H}$-bonding network, encompassing $\mathrm{NH}$ atoms of the tren cap, inverted pyrroles and amide functions. Interestingly, one molecule of TFA- occupies the crypto environment, and is stabilized by $\mathrm{H}$-bonds in a bis-anchor fashion, both with protonated pyrroles $(\mathrm{dN} 3-\mathrm{O} 1=2.83 \AA$ and $\mathrm{dN} 5-02=2.79 \AA)$ and protonated nitrogen atoms of the tren (dFa-N1 = $2.90 \AA$ and dFb-Nt = $2.89 \AA$, see dashed lines). Such an endo binding mode differs from that reported for a MSA counterion interacting with the convex face of a regular triangular hexaphyrin ( $\mathrm{CH}-\mathrm{O}$ bifurcated bonds). ${ }^{7 \mathrm{~d}, 11 \mathrm{~b}}$ This network of $\mathrm{H}$-bonds involving both protonated hexaphyrin and

\section{Conflicts of interest}

There are no conflicts to declare.

\section{Notes and references}

1 For recent reviews, see: (a) T. Tanaka and A. Osuka, Chem. Rev., 2017, 117, 2584-2640; (b) Y. M. Sung, J. Oh, W.-Y. Cha, W. Kim, J. M. Lim, M.-C. Yoon and D. Kim, Chem. Rev., 2017, 117, 2257-2312; (c) B. Szyszko, M. J. Białek, E. PacholskaDudziak and L. Latos-Grażyński, Chem. Rev., 2017, 117, 28392909.

2 (a) A. Osuka and S. Saito, Chem. Commun., 2011, 47, 43304339. (b) M. Pawlicki and L. Latos-Grażyński, Chem. Asian J., 2015, 10, 1438-1451.

3 T. Stuyver, M. Perrin, P. Geerlings, F. De Proft and M. Alonso, J. Am. Chem. Soc., 2018, 140, 1313-1326.

4 (a) M. Torrent-Sucarrat, S. Navarro, E. Marcos, J. M. Anglada and J. M. Luis, J. Phys. Chem. C, 2017, 121, 19348-19357; (b) T. Mori, T. Tanaka, T. Higashino, K. Yoshida and A. Osuka, J. Phys. Chem. A, 2016, 120, 4241-4248.

5 H. Ruffin, G. Nyame Mendendy Boussambe, T. Roisnel, V. Dorcet, B. Boitrel and S. Le Gac, J. Am. Chem. Soc., 2017, 139, 13847-13857.

6 (a) S. Mori and A. Osuka, J. Am. Chem. Soc., 2005, 127, 80308031; (b) Shigeki Mori, Soji Shimizu, A. Ryuichiro Taniguchi and A. Osuka, Inorg. Chem., 2005, 44, 4127-4129; (c) Y. Tanaka, S. Saito, S. Mori, N. Aratani, H. Shinokubo, N. Shibata, Y. Higuchi, Z. S. Yoon, K. S. Kim, S. B. Noh, J. K. Park, tren units traduces a good host-guest complementarity, which likely cannot be achieved either with $\mathbf{2}$ bearing a more distant tren cap, nor by replacing TFA by MSA.

This study has evidenced multiple conformation and aromaticity changes specific to the smallest tren-capped hexaphyrin 1 upon protonation. Notably, changing the shape of the hexaphyrin (rectangle -> Möbius -> triangle) deeply influences the tren cap geometry (extended -> shrunk -> crypto), affording different cage environments (Scheme 1). The triprotonated state of the tren unit may contribute to stabilize a diprotonated Möbius aromatic conformation of the hexaphyrin, that would otherwise isomerize into a triangular one. ${ }^{7 d, 11 b}$ This Möbius-to-triangular shape shifting process is observed upon the fourth protonation of the tren unit, which may reset up the $\mathrm{H}$-bonding network triggering hexaphyrin isomerization.

These results underlie a new function of the hexaphyrin frame that is to control the shape of a confined space, and the preorganization of an appended (potential) metal binding site. It further strengthens an emerging approach which consists in the use of flexible expanded porphyrins as switchable devices to control spatial organization of attached sub-units. ${ }^{5,11}$ In particular, the "crypto-bowl-shape" conformation of the ligand observed in the solid state, with a hosted TFA- counterion, is of particular interest for the design of new metallo-receptors with switchable aromaticity. ${ }^{13}$ Work along this line is in progress in our laboratory.

D. Kim and A. Osuka, Angew. Chem. Int. Ed., 2008, 47, 681684; (d) H. Rath, N. Aratani, J. M. Lim, J. S. Lee, D. Kim, H. Shinokubo and A. Osuka, Chem. Commun., 2009, 3762-3764.

7 (a) T. Koide, K. Youfu, S. Saito and A. Osuka, Chem. Commun., 2009, 6047-6049; (b) M. Stępień, B. Szyszko and L. LatosGrażyński, J. Am. Chem. Soc., 2010, 132, 3140-3152; (c) W.-Y. Cha, J. M. Lim, M.-C. Yoon, Y. M. Sung, B. S. Lee, S. Katsumata, M. Suzuki, H. Mori, Y. Ikawa, H. Furuta, A. Osuka and D. Kim, Chem. Eur. J., 2012, 18, 15838-15844; (d) S.-I. Ishida, T. Higashino, S. Mori, H. Mori, N. Aratani, T. Tanaka, J. M. Lim, D. Kim and A. Osuka, Angew. Chem. Int. Ed., 2014, 53, 3427-3431; (e) K. Naoda, H. Mori, J. Oh, K. H. Park, D. Kim and A. Osuka, J. Org. Chem., 2015, 80, 11726-11733.

8 (a) M. Stępień, L. Latos-Grażyński, N. Sprutta, P. Chwalisz and L. Szterenberg, Angew. Chem. Int. Ed., 2007, 46, 7869-7873;

(b) J. Sankar, S. Mori, S. Saito, H. Rath, M. Suzuki, Y. Inokuma, H. Shinokubo, K. Suk Kim, Z. S. Yoon, J.-Y. Shin, J. M. Lim, Y. Matsuzaki, O. Matsushita, A. Muranaka, N. Kobayashi, D. Kim and A. Osuka, J. Am. Chem. Soc., 2008, 130, 13568-13579; (c) M.-C. Yoon, P. Kim, H. Yoo, S. Shimizu, T. Koide, S. Tokuji, S. Saito, A. Osuka and D. Kim, J. Phys. Chem. B, 2011, 115, 14928-14937.

9 (a) E. Heilbronner, Tetrahedron Lett., 1964, 5, 1923-1928; (b) H. E. Zimmerman, J. Am. Chem. Soc., 1966, 88, 1564-1565; (c) H. S. Rzepa, Chem. Rev., 2005, 105, 3697-3715; (d) R. Herges, Chem. Rev., 2006, 106, 4820-4842.

10 For pioneering examples of molecular Möbius rings, see: (a) D. M. Walba, R. M. Richards and R. C. Haltiwanger, J. Am. Chem. Soc., 1982, 104, 3219-3221; (b) D. Ajami, O. Oeckler, A. Simon and R. Herges, Nature, 2003, 426, 819-821; (c) C. Castro, Z. Chen, C. S. Wannere, H. Jiao, W. L. Karney, M. 
Mauksch, R. Puchta, N. J. R. van Eikema Hommes and P. von Ragué Schleyer, J. Am. Chem. Soc., 2005, 127, 2425-2432.

11 (a) M. Ménand, M. Sollogoub, B. Boitrel, S. Le Gac, Angew. Chem. Int. Ed., 2016, 55, 297-301; (b) S. Le Gac, B. Boitrel, M. Sollogoub and M. Ménand, Chem. Commun., 2016, 52, $9347-$ 9350; (c) M. Ménand, M. Sollogoub, B. Boitrel and S. Le Gac, Chem. Eur. J., 2018, 24, 5804-5812.

12 The moderate quality of the crystal (SI), as a result of disordered exo-TFA molecules, does not encourage fine hexaphyrin bond lengths analysis (e.g. HOMA value determination).

13 For recent bowl-shape hosts and catalysts made of a calixarene or a cyclotriveratrilene capped with a tren unit, see: (a) S. Zahim, L. A. Wickramasinghe, G. Evano, I. Jabin, R. R. Schrock and P. Müller, Org. Lett., 2016, 18, 1570-1573; (b) J. Yang, B. Chatelet, V. Dufaud, D. Hérault, S. MichaudChevallier, V. Robert, J.-P. Dutasta and A. Martinez, Angew. Chem. Int. Ed., 2018, 57, 14212-14215. 